\title{
Notes on the vocalizations of Rose-breasted Chat (Granatellus pelzelni)
}

\section{Peter Boesman}

In the following we briefly analyze and compare voice of the two races of Rose-breasted Chat (Granatellus pelzelni). We also try to quantify the extent of any vocal differences using the criteria proposed by Tobias et al. (2010), as a support for taxonomic review.

We have made use of sound recordings available on-line from Xeno Canto (XC).

A comparison of song, illustrated with sonograms:
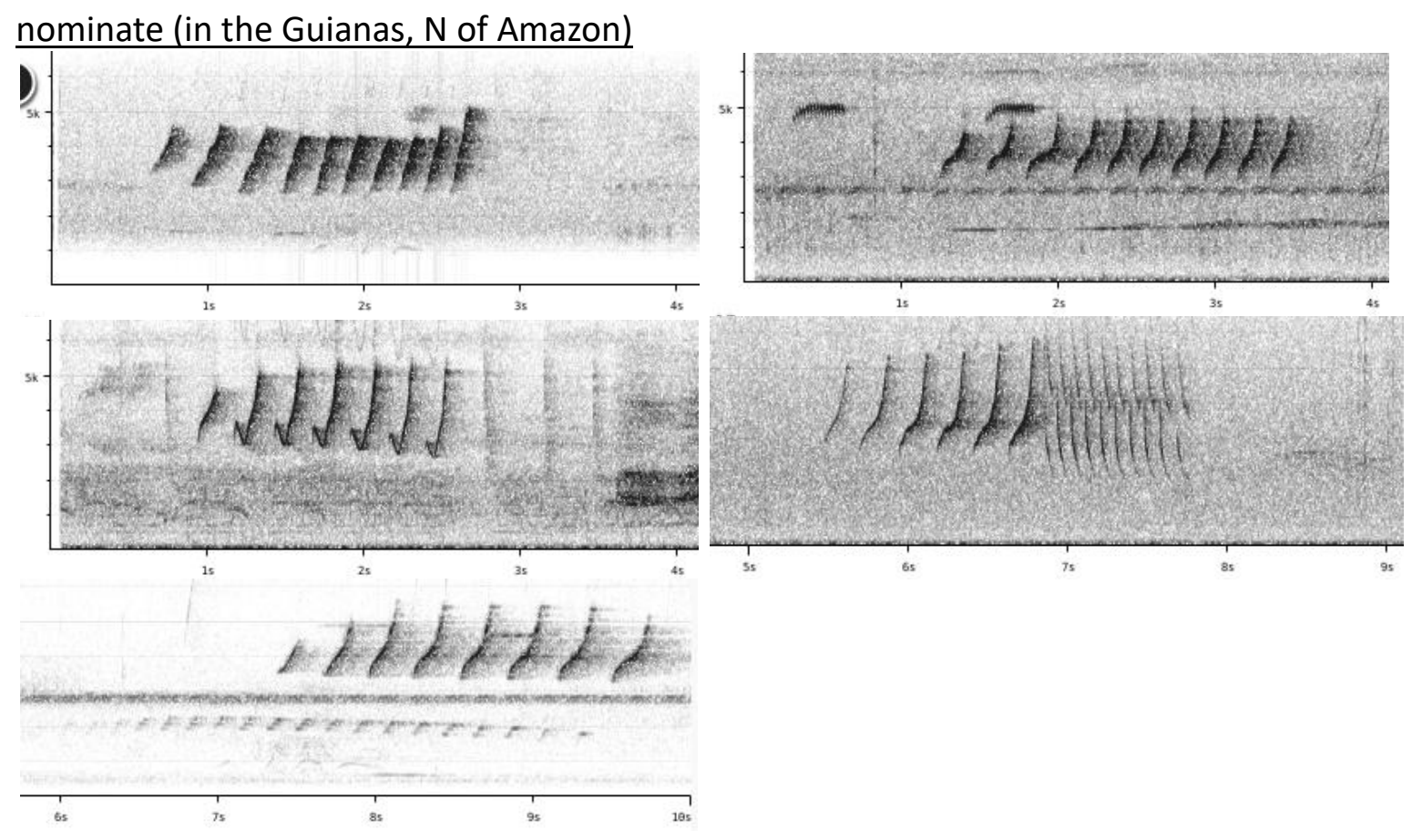

nominate (S of Amazon)
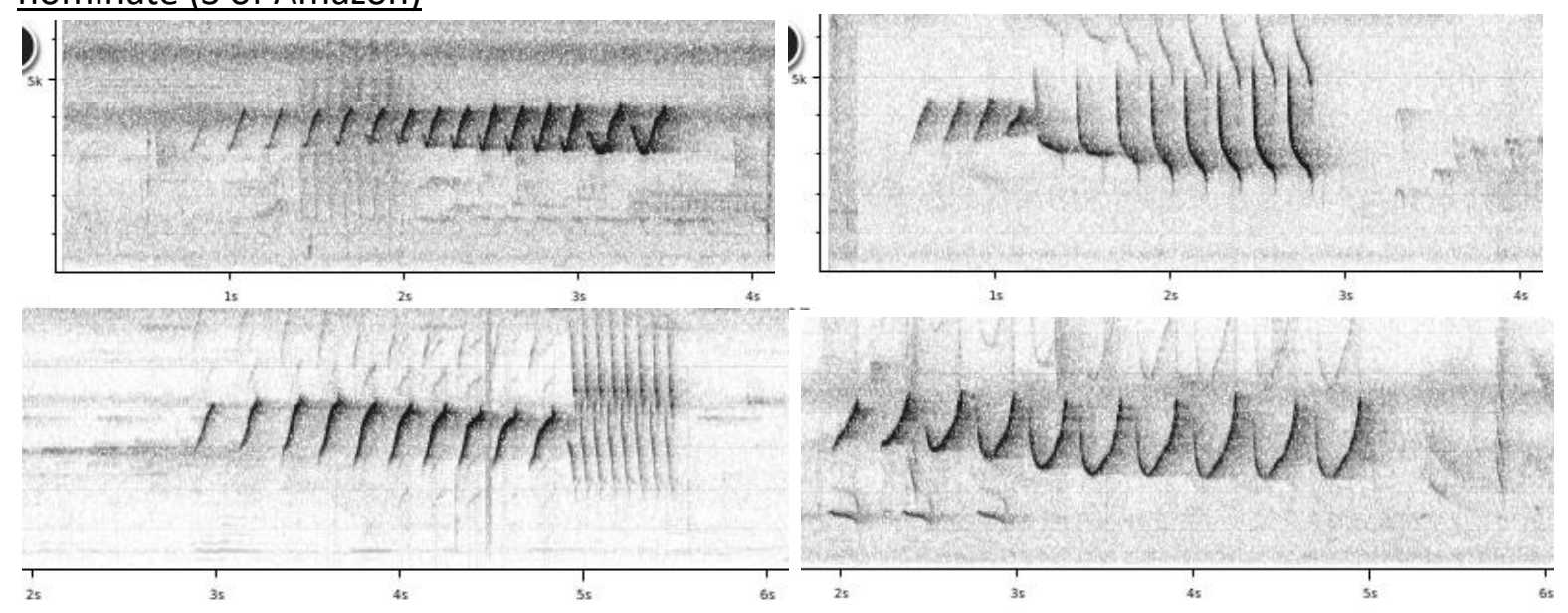


\section{HANDBOOK OF THE Allue}

\section{ORNITHOLOGICAL NOTES}
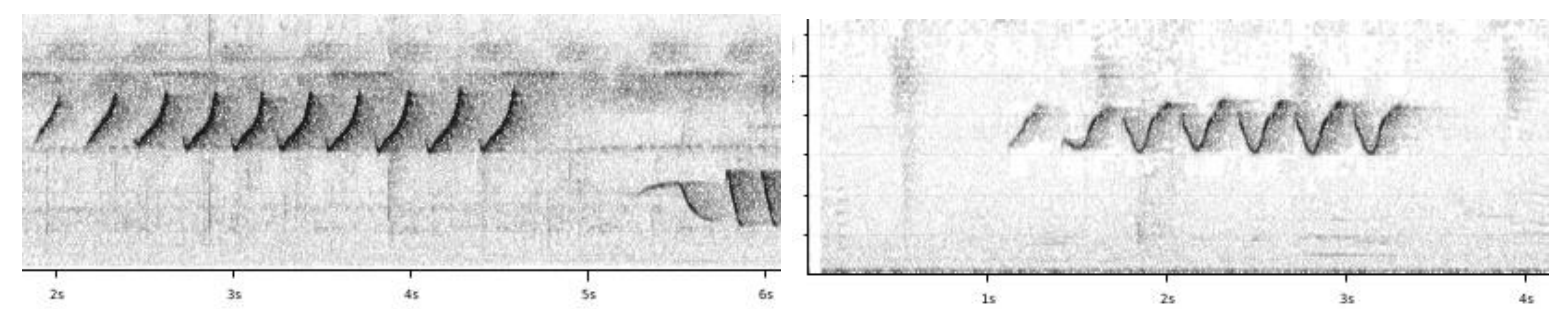

paraensis $(\mathrm{n}=4)$

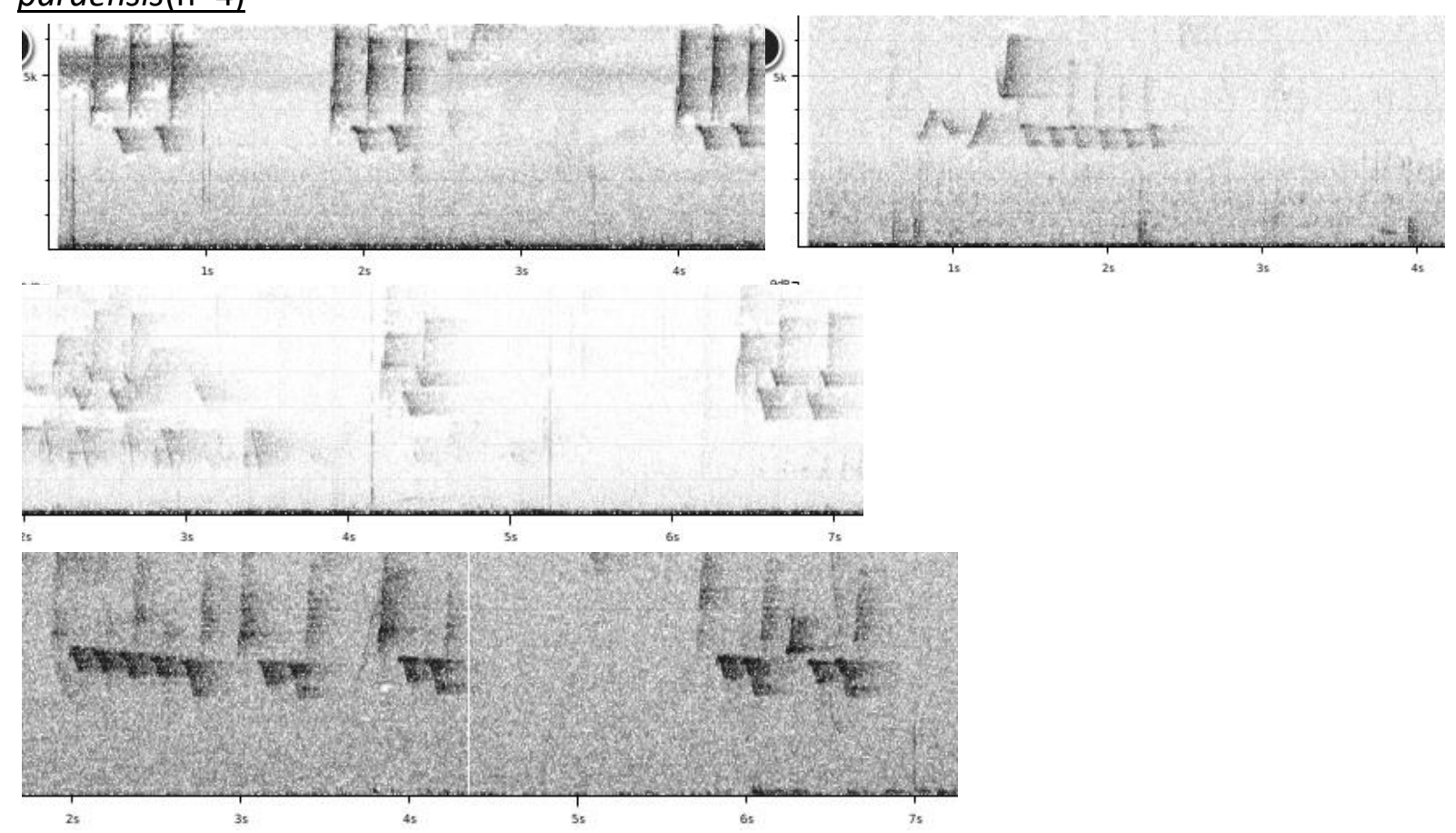

There is a striking difference in song between paraensis and nominate!

Nominate in all regions ( $\mathrm{N}$ and $\mathrm{S}$ of Amazon) has a song consisting of a series of repeated notes which are all rather similar-shaped (sometimes ending with a different trilled part or 2 series of repeated notes). Typically 6-15 repeated notes. Phrase length $1.8-3 \mathrm{~s}$. Notes have a freq. range of c. $0.7-3 \mathrm{kHz}$.

paraensis seemingly has a song which is a variable, rather rhythmic phrase with alternating a mellow low-pitched down-slurred whistle (or a short series of these) and harsher short highpitched notes. Repeats $1-6$. Phrase length $0.5-1.5 \mathrm{~s}$. Mellow notes have a narrow frequency range of c. $0.7-1.1 \mathrm{kHz}$.

The vocal difference can be scored based on paraensis having less repeated notes (score 23 ), shorter song phrases (score 2-3) and different note shapes (1-2), with mellow notes having a much narrower freq. range (2), which leads to a total vocal score of about 5. This obviously is based on only 4 examples of paraensis, and thus needs further confirmation, but nevertheless seems quite convincing.

The typical 'jrt' call of nominate is apparently not recorded from paraensis, nor any other possibly homologous call note. 
As a final remark, both song types discussed here are also very different from the two Granatellus species in Mexico.

This note was finalized on 29th June 2016, using sound recordings available on-line at that moment. We would like to thank the many sound recordists who placed their recordings for this species on XC, in particular Alexander Lees and Sidnei de Melo Dantas for recordings of the race paraensis.

\section{References}

Tobias, J.A., Seddon, N., Spottiswoode, C.N., Pilgrim, J.D., Fishpool, L.D.C. \& Collar, N.J. (2010). Quantitative criteria for species delimitation. Ibis 152(4): 724-746.

\section{Recommended citation}

Boesman, P. (2016). Notes on the vocalizations of Rose-breasted Chat (Granatellus pelzelni). HBW Alive Ornithological Note 384. In: Handbook of the Birds of the World Alive. Lynx Edicions, Barcelona. (retrieved from http://www.hbw.com/node/1252941 on 30 November 2016). 